his patients. At a meeting held at Mr. Tamplin's house before the Annual Court, my view was unanimously adopted, and by none more cordially than by Messrs. Tamplin and Adams themselves.

Mr. Brodhurst admits having obtained rotes through his friends for the Special Court. I find by the hospital books that 81 annual subscribers at $£ 11$ s. each, entitled to vote, were made for the Special Court. Admitting that only half were made by $\mathrm{Mr}$. Brodhurst's friends, if to 40 we add the 32 made by Mr. Brodhurst himself at the Annual Court, and we except the committee and three ladies, who held up their small fair hands against the canse of conciliation, we shall find that there were no more independent $v$ : ites given against the senior surgeons at the Special than at the Annual Court, the number being 99 to 98 .

Special hospitals are apt to degenerate when the guiding genius that inaugurates thera is withdrawn, and this is a fate not unlikely to attend the Royal Orthopædic Hospital. Whether it will die under the blighting influence of a public inquiry, or whether it will continue its useful mission, will depend upon the course now taken by the committee.

I am, Sir, jour obedient servant,

Inverlochy Castle, Kingussie, April 22nd, 1872.

ABINGER.

To the Editor of ThE LANCET.

SIR,-In Mr. Brodhurst's letter, published in your journal on the 13th of April, it is stated that "prior to most of the Annual and Special Courts an active canvass for new governors has taken place." Now, Sir, I beg to state that I have been connected with the Royal Orthopædic Hospital from its foundation, thirty-four years since, and I am not aware that such a practice has ever been followed. It is to be regretted that Mr. Brodhurst himself voted on the occasion of the Annual Court in favour of the report of the Committee, containing a censure upon Mr. Adams and myself, and which compelled us to tender our resignations.

I am, Sir, yours, \&c.,

Old Burlington-street, W., April 23rd, 1872. $\quad$ R. W. TAMPLIN.

** We published last week a letter from Mr. Adams, in which he said that he should shortly "ask for an authoritative judgment" upon the recent events at the Royal Orthopædic Hospital. Surely the pledge thus given is one that should be redeemed without delay, so that this most painful and discreditable controversy may be finally set at rest.-ED. L.

\section{CHILDBIRTH AFTER INTERMENT.}

\section{To the Editor of THE LANCET.}

Srr,-In The Lancet of April 13th you have raised the following interesting question, "Can a woman be delivered of a child after she is buried?" In answer to it I beg to forward the six following cases of delivery after death without the aid of art.

Rudolph Camerarius* tells us of a Spanish inquisitor who caused a pregnant woman to be hanged. Four hours after the death of the unhappy mother, while still hanging on the gibbet, two living children fell from her womb. This occurred in 1551.

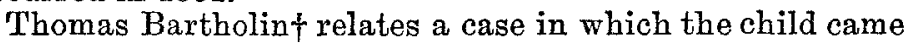
into the world nearly two days after the death of the mother, three midwives having exhausted their art in attempting to deliver her.

Cornius writes of a woman of Madrid, of the illustrious family of Lasso, who having been reputed dead, was placed in the family tomb, which being opened some months after they found the corpse holding a dead infant on its right arm.

G. A. Reiss $\S$ says the wife of François Arevallos de Suesso fell ill in that town towards the last months of her pregnancy. Being dead a few days, or having been reputed so, she was buried. The husband, who had been diligently sought for in a distant place where he had gone on business,

* Silloge Memorabilium Medecin.

+ Act. Hafn., anno 1679 .

₹ Anecdotes \&c. dans les Accouchmens. Sue.

$\$$ Elysius Corpus jucundarum quæstionum. arrived towards the middle of the night; learning that his wife, whom he loved much, was buried, he wished the satisfaction of seeing her once more. He went to the church and caused her to be exhumed. Scarcely had they opened the coffin when they heard the cries of a child. Everyone was seized with astonishment; they called the justice, the priests, and many others, and when the shroud was lifted they saw the head of the child, which was endeavouring to extricate the rest of its body. It was taken away alive, and lived long after under the name of "Fils de la terre."

Dr. Harvey* asserts the following:- "A certain woman here amongst us (I speak it knowingly) was (being dead over night) left alone in her chamber; but the next morning an infant was there found between her legs, which had by his own force wrought his release. Gregorius Nymmanust hath collected certain examples of this nature out of approved authors."

Percivall Willughby gives us one of the most authentic and best recorded cases of childbirth after interment. " There was a strange yet true accident which happened at Ashhurn, in Darbyshire. At the first hearing of it, and for that I would be more certainly informed of the truth, I sent unto my friend Mr. Abraham Mercer, lecturer of ye place, desiring him to let me have a true relation of it, and from him I received this certificat, December the 9 th, 1667 .

" Emme, the wife of Thomas Toplace, was five dayes in labour. The sixth day shee had a medicine given her to ease her paines by a Doctor of Divinity (Dr. Kettleby) pretending some small skill in physick. After the taking of the medicine in the evening shee was supposed to bee dead, and after nine o'clock that night shee was buried. As shee was carried to the grave, some thought that they heard a rumbling in the coffin. A noise was heard like the breaking of a bladder, after which followed a noisome smell. Shee had an ill-conditioned man to her husband, that frequently gave her evil words, and oft blows with them. Her husband, with his mother and the midwife, with some other women, made haste to bury her, having, among other things, filled her mouth with hurds (tow). Several women were much troubled at her hasty burial, and thought that shee was not dead. Among this company there was one, Anne Chad wick by name, that returned to the grave, and laying her ear to the ground, shee heard a sighing, as it might be of one dying in that grave. A souldier being with her heard the same, and he affirmed, besides the sighing, that hee heard the crying of a child. They went to Mr. Legg, a justice of the peace in that town, and told him of it, as also the minister and others, what noise was heard in the grave, and Anne Chadwick said that shee beleeved that the woman was alive. The earth was cast off from the coffin, and the coffin was found somewhat opened, where formerly the bords were joined together, with a ridg at the top, and the coffin was hot. After that it was opened, the womans hand was seen bare, and some saw hurds lying on her breast, and in her hand, with which her mouth had been stopt by her husband's friends. And it was beleeved that the buried woman had pulled those hurds out of her mouth with her own hand after that shee was interred. Another woman put down her hand and found a child delivered in the coffin, and descended as low as her knees, or lower, with one hand in the mouth and the other extended by the side: and the after-burden was also come from her. Her husband, with his mother and the midwife, with others which laid her forth (after her supposed death) were much displeased that the grave was opened, and at the murmuring of the people, hee gave threatening words against some of the company ; but at last hee thought that it was his best way to bee quiet and to let all their words and deeds sleep with his deceased wife. I shall leave her husband, and his mother, and the women that would have her so suddenly buried to be censured as each particular person pleaseth.'

"Whether this woman was alive or dead whell she was buried? Elizabeth Shent, with her mother, Anne Chadwick, with others, affirm these passages to be true, and the coffin was left open all that night that the bodies of the mother and the child might bee seen by all those that would look on her. Mr. Abraham Mercer, also, took a cer.

* Anatomical Exercitations, 1653, p. 492.

† "Dissertatio de Vita Fotus in Utero," 1628. See also J. G. Müller, "De Partu Post Mortem Matris," 1714.

$\$$ MS. copy of Country Midwife's Opusoulum, in the possession of the writer. 
tificat out of the Parish Register book, where it was thus recorded :-April ye 20, 1650, was buried Emme, the wife of Thomas Toplace, who was found delivered of a child after shee had lain two hours in the grave."

Sue* informs us that it is the custom of certain ignorant women, who enshroud those dying pregnant, to shut up in the coffin with the corpse a needle, scissors, and thread, which, he says, is a proof that experience has convinced them that women can be delivered after death. Believe me, Sir, yours, \&c.,

Upper Wimpole-street, April, 1872. J. H. Aveling, M.D.

\section{CAUSATION OF ENTERIC FEVER. To the Editor of THE LaNcer.}

SIR,-The interest as to the causes of the illness of his Royal Highness the Prince of Wales having not as yet quite died out, I think that a statement of the following facts may perhaps prove acceptable to the readers of your journal.

A short time since, when passing along the principal street of the town of Tiverton, my attention was attracted by some men working at a drain which they had opened across the road, and on looking into it, I saw a large collection of dark-coloured fluid possessing all the well-known characteristics of highly concentrated sewage. On inquiry, I found that the drain, having become obstructed, had burst, and that an overflow of sewage had taken place into the well supplying the house with water, the bad taste and odour of which had first directed attention to the defective condition of the drainage.

A few days afterwards, I was much surprised at being requested by Mr. Reed, of Tiverton, to visit with him in consultation no less than three well-marked cases of typhoid fever in the house from which the drain alluded to proceeded, and also to learn from him that a fourth case of the same disease had just been removed to his home at a distance, in the person of a young man employed on the premises. Mr. Reed moreover informed me that in the house immediately opposite, and connected with the same drain, two cases of typhoid fever had also occurred, upon which he was also in attendance; and I have since ascertained that the occupants of that house, finding the water of the well from which they were usually supplied disagreeable both as to taste and smell, had applied for water to the house opposite, and had made use of the water from the well also contaminated by an overflow of sewage. From a defect in one drain we have thus no less than six wellmarked cases of typhoid fever, to which no other cause can be assigned. They all progressed favourably and terminated in recovery without any serious intestinal complication, the period of incubation having been about twelve days.

The narration of their occurrence may, I think, prove interesting, as showing that typhoid fever may without doubt be occasioned simply by an overflow of sewage into water used for drinking purposes, and without any admixture of the excreta of individuals already affected with that disease, no other cases having previously occurred in the immediate vicinity.

I remain, Sir, your most obedient servant, HenRY DOWNES, M.D. Tiverton, Deron, April 6th, 1872. Deputy Inspector-General of Hospitals.

\section{THE HANWELL ASYLUM.}

\section{To the Editor of The LaNCET.}

SIR,-In reference to a letter on this subject, which appeared in your last number, signed "M.D. Cantab.," allow me to state that I am not the assistant medical officer alluded to, nor am I a candidate for the resident medical officer's appointment, vacant by the retirement of Dr. Begley. Whoever may aspire to $\mathrm{Dr}$. Conolly's mantle, I only hope he may find it.

I am, Sir, your obedient servant,

Middlesex Lunatic Asylum, Hanwell, W. April 20th, 1872.

P.S.-My reason for making the above statement is that many of my professional friends and others are apparently nnder the impression that I am seeking the post.

* Op. cit.

\section{MILITIA SURGEONS.}

To the Editor of THE LANCET.

SrR,-Looking at the undecided answer of Mr. Cardwell to Sir E. Lacon, it is rather puzzling to determine what steps to take in the matter. Are the surgeons expected to take the initiative, and send in their clains at once, or wait until the new scheme is matured? Time is of vital importance to those who, like myself, will have to seek for an opening for practice, and we cannot under such circumstances know our fate too soon. If we cannot get something more positive from the Secretary for War, I would suggest that two meetings be organised, one in London for the southern, and the other in Birmingham for the northern counties, to take steps for drawing up a memorial, and appointing a deputation accompanied by our M.P.s to wait upon Mr. Cardwell and fully represent our case.

April, 1872. I am, Sir, your obedient servant, MrLitia.

\section{GLASGOW.}

(FROM OUR OWN CORRESPONDHNT.)

IT appears that something of the nature of a coup d'état is being attempted in regard to our sanitary affairs. A committee of the Police Board has submitted a report recommending the dismissal of the whole medical sanitary staff, and the appointment of one medical officer who would devote his entire time to the duties of the department. Rumour has it that the proposed alteration has been instigated in the interest of one of the present subordinates, who, it is averred, will most probably receive the appointment. It must strike everyone that, if a reorganisation of the department be needed, it might have been carried out with a little more consideration for the feelings of the present medical officer. A reform begun by ignoring his existence is initiated under too questionable auspices to enable us to augur much good from it. Dr. Gairdner has never displayed tenacity of place; he is, besides, a gentleman of acknowledged attainments in sanitary science, and has admittedly discharged his duties with efficiency. He has published a very pointed and dignified remonstrance. That his official connexion with the sanitary office, however wellqualified he may be for the duties, is somewhat derogatory to his status as Professor of Medicine in the University, and consequently prejudicial to his professional and social position, is, I believe, the general opinion of the profession in Glasgow. Should he lose the appointment, he will not thereby lose in the estimation of his professional brethren.

The buildings of the new Unfversity Hospital are making very slow prooress, on account of want of funds. The University authorities have displayed an inexplicable want of energy in the matter. The citizens of Glasgow have ever responded promptly to an appeal for such an object as increased hospital accommodation, provided the appeal were properly made. The governing body of the University must have a large amount of patience if they are content to see the subscriptions come in, as at present, in driblets. They cannot but see that the great distance between the places of systematic and clinical tuition is not only productive of much inconvenience to the students, but is most prejudicial to the medical school.

The alterations in the medical organisation of the Infirmary, made some years ago, have now had so far a fair trial. The throwing open the privilege of giving clinical lectures to all the physicians and surgeons has, I understand, been attended with excellent results. Whether the regulation respecting continuity of tenure of office will have equally beneficial effects remains yet to be seen. 23rd April, 1872.

\section{NEWCASTLE-ON-TYNE}

\section{(FROM OUR OWN CORRESPONDENT.)}

THe Annual Report of our Infirmary mentions that, owing in part to the improved cooking apparatus, the very great consumption of stimulants had been considerably diminished. In the former year $\$ 1590 s .6 d$. was spent in 